\title{
Juridical review on recruitment of foreign workers
}

\author{
Rizkan Zulyadi* and Muhammad Yusrizal Adi Syaputra \\ Faculty of law, University of Medan Area, Medan, Indonesia
}

\begin{abstract}
Manpower development is an integral part of national development based on Pancasila and the 1945 Constitution, which is implemented through the development of a reliable Indonesian workers for the realization of a prosperous Indonesian society. Manpower development must be fairly regulated so as to provide comprehensive protection for Indonesian workers. On March 26, 2018 President Jokowi signed the Presidential Regulation No. 20 of 2018 concerning Use of Foreign Workers, this regulation is considered to harm Indonesian workers. This research use a normative method and juridical approach with Theory of Popular Sovereignty by John Locke. Normative legal research is a research that discusses the legal aspect, by conducting library research in terms of comparative law or legal history oriented to the applicable laws and regulations. Based on Theory of Popular Sovereignty, Presidential Regulation 20 of 2018 contradictory to the Manpower Act especially about the Plan of Use of Foreign Workers. Even the regulation does not pay attention to the interests of the people to get a job and only prioritize the entry of investment to Indonesia.
\end{abstract}

\section{Introduction}

Indonesia is the largest archipelagic country in the world with abundant natural wealth. This natural wealth is the basic capital given by Allah the Almighty God to the nation of Indonesia as a managed resource to improve the quality of life and welfare of the Indonesian nation. As a legal state based on Pancasila and the 1945 Constitution, the management of natural resources must be implemented based on the basic ideas and concepts of the state contained in Pancasila and the 1945 Constitution.

The meaning of the state is not merely a territorial nation that has full sovereignty because the territory is only a small part of the country. The largest and most substantial part of the state is the unity of politics. The state is the basic institution of political power. Therefore, the state is a law, a territory, a constitution, a society, and a purpose.

The state is not something concrete, but an abstract concept of political attitudes and power contained in it. ${ }^{[1]}$ According to Mirza Nasution ${ }^{\dagger}$,_the state is an organization among a group or several groups of people collectively inhabiting a certain region that recognizes the

\footnotetext{
* Corresponding Author: rizkanzulyadi.uma@gmail.com
} 
existence of a government that takes care of their order and salvation. In a region, the state organization is not the only organization, but there are other organizations (religious, party, community that have their own personalities apart from state problems). Among these organizations, the state is the primary organization in a region because it has an authorized government and is able to intervene in the field of other organizations. An understanding of the existence of the state and the existence of human beings, similar to the view that the social community means the diverse unity of individuals and the actions of a number of individuals in the background of the need for state norms. This is what affirms that the state is not merely a legal reality, but a social reality. The reality of law requires the existence of a social reality recognized by law, while the reality of law as a reality to be obeyed by social reality. ${ }^{[2]}$

The Indonesian nation has poured the goals and ideals of Indonesian independence into the preamble on the fourth paragraph of the 1945 Constitution which reads "....... to form a government of the state of Indonesia which shall protect all the people of Indonesia and all the independence and the land that has been struggled for, and to improve public welfare, to educate the life of the people and to participate toward the establishment of a world order based on freedom, perpetual peace and social justice, therefore the independence of Indonesia shall be formulated into a constitution of the Republic of Indonesia which shall be built into a sovereign state based on a belief in the One and Only God, just and civilised humanity, the unity of Indonesia, and democratic life led by wisdom of thoughts in deliberation amongst representatives of the people, and achieving social justice for all the people of Indonesia ..... ", and more firmly stipulated in Article 27 Paragraph (2) of the 1945 Constitution which states" every citizen shall have the right to work and to earn humane livelihood ". Therefore it is the duty and obligation of state (government) to provide employment and prepare the development of competent Indonesian workers and able to compete in the global era, in order to advance the general welfare of the Indonesian nation.

Manpower developmenti s an integral part of national development based on Pancasila and the 1945 Constitution, which is implemented through the development of a reliable Indonesian workers for the realization of a prosperous Indonesian society. Manpower development must befairly regulated so as to provide comprehensive protection for Indonesian workers. Manpower development aims to develop the potential of human resources, improvement of productivity and competitiveness of Indonesian workers. The government as the state organizeris obliged to prioritize the needs of the Indonesian workers in the manpower policy.

Peter L. Berger says that there is no life of a nation that does not face any problems at all, such as the problems faced by developing countries such as hunger, illness, high mortality, ignorance, backwardness, shelter needs, and lack of the number of job availability. Development is a set of human efforts to direct social and cultural change in accordance with the objectives of national and state life, which is to achieve the growth of civilization of social life and culture on the basis of established targets. Thus development is a matter for the government. ${ }^{[3]}$

On March 26, 2018 President Jokowi signed the Presidential Regulation No. 20 of 2018 concerning Use of Foreign Workers, to make it easier for foreignworkers entering Indonesia in the hope that Presidential Regulation will increase investment and national economy. However,the Presidential Regulation is considered potentially violating Act Number 13 of 2003 concerning Manpower (Manpower Act). The policy is also considered to violate Article 27 paragraph (2) of the 1945 Constitution which states that "Every citizen is entitled to decent work and livelihood for humanity".

In the Presidential Regulation Number 20 of 2018 mentioned, every employer of foreign workers who use foreign workers must have a Plan for the Use of ForeignWorkers (PUFW) 
approved by ministers or appointed officials, but the employers of foreign workers are not required to have PUFW to employ foreign workers if Shareholders who are members of the board of directors or members of the board of commissioners to the employers of foreign workers; Diplomatic and consular officers to representatives of foreign countries; and foreign workers on the type of work the government needs.

Author assume the Presidential Regulation issued by President Jokowi is a political policy that only gives benefits to the businessmen and foreign investors. This political policy had weaken the spirit of Indonesian workers who need jobs.Presidential Regulation which is a political policy of President Jokowi should be made to strengthen the rules of the use of foreign workers in Indonesia and reduce foreign workers entry, not to facilitate and causes many foreign workers comes to Indonesia.

\section{Formulation of the Problem}

The problem of this research is formulated as: how is the consequences of Presidential Regulation number 20 of 2018 to Indonesian people especially the workers based on Popular Sovereignty Theory?

\section{Research Method}

This research is a normative legal research. Normative legal research is a research that discusses the legal aspect, by conducting library research in terms of comparative law or legal history oriented to the applicable laws and regulations. ${ }^{[4]}$ This normative legal research use statutory approaches which relevant to this legal research. ${ }^{[5]}$ The data were analyzed using a comparative approach by conducting comparative law study which oriented to legal theory approach. The method used was comparing a certain legal system with another, which has more or less similarities, so that the similarities and differences between the legal systems were found. ${ }^{[6]}$

The data were collected using a library research method by documenting relevant literature and provisions of legislation related to the problems to be answered in this research.

\section{Literature Review}

The Popular Sovereignty Theory by John Locke argues that the people are sovereign in a country. It is the people who decide the will of the state, the people decide who becomes the state government is. ${ }^{\S}$ This theory explains at the beginning, humans live freely, then humans were joined to form a social contract. In this social contract, each individual hand over some personal affairs to the community, and the community then gave his authority to the king. So the king actually got his authority from the people.The king got the authority from the people, thus who has the highest authority is the people, or in other words the sovereign is the people. The position of the king is only as the executor of the will of the nation which has been decided or desired by the people. According to popular sovereignty theory, the people as the unity formed by individuals, these individuals formed unity through an agreement. ${ }^{* *}$ The unity of society has formed a general opinion called Vontole Generale, Vontole Generale is considered as a reflection of the will and the general will. ${ }^{[7]}$

Based on popular sovereignty theory, the purpose of the state is to enforce the law and guarantee the freedom of its citizens. Freedom here is freedom in accordance with applicable 
laws. The law itself is an incarnation of the people. Thus, the law is the embodiment of the will of the people. So the people are the highest authorities.

The will of the people is usually collected through the implementation of General Election. General Elections can determine who is the ruler and govern the lives of the people, and can also determine who will be the representative of the people in the House of Representatives and determine what the will of the people. Popular sovereignty theory is affirmed in Article 1 paragraph (2) of the 1945 Constitution "Sovereignty is in the hands of the people and implemented according to the Constitution". ${ }^{\dagger \dagger}$

\section{Result and Discussion}

Increasing the number of foreigners who entering Indonesia is not only have positive effect but also a negative effect, it is necessary to have a selective regulation from the government to provide the terms and conditions for the foreigners to entering territory of the Republic of Indonesia. The foreigners entering Indonesia must be in accordance with a selective policy, which includes entry, residence, and exit from the territory of Indonesia, based on this principle only foreigners who benefit Indonesia alone who can be granted entry, permission to be in Indonesia, while for permission out after settle his obligations in Indonesia then he can get out of Indonesia.

Supervision of foreigners includes the entry and the exit of foreigners to and from the territory of Indonesia, and the presence and activities of foreigners in the territory of Indonesia. Oversight of a foreigner as a series of activities has basically been initiated and undertaken by representatives of the Republic of Indonesia abroad when receiving a visa application. Subsequent monitoring is carried out by immigration officials at immigration checkpoints when immigration officials with their autonomous authority decide to deny or grant residency permits in accordance with their visas. Furthermore, the supervision shall move to the immigration office whose working area covers the residence of the foreigner. Of all established immigration procedures, it should be understood that its operations are carried out on the basis of a selective immigration law policy.

Presidential Regulation Number 20 of 2018 concerning the Use of Foreign Workers is expected to facilitate foreign workers entering Indonesia which leads to increased investment and improvement of national economy. In this Presidential Regulation mentioned, every employers of foreign workers who use foreign workers must have a Plan for the Use of Foreign Workers (RPTKA) endorsed by ministers or appointed officials. However, the employers of foreign workers are not required to have RPTKA to employ foreign workers who are: Shareholders who are members of the board of directors or members of the board of commissioners to the employers of foreign workers; Diplomatic and consular officials to representatives of foreign countries; Foreign workers on the type of work the government needs. For emergency and urgent work, according to Presidential Regulation of Use of Foreign Workers, employers of foreign workers may employ foreign workers by applying for RPTKA approval to the appointed minister or official no longer than two working days after the foreign workers work. In this regulation also affirmed, every foreign worker who work in Indonesia is obliged to have a limited residenced visa (vitas) for work petitioned by employer of foreign workers to the minister in charge of government affairs in the field of law and human rights or appointed officials by attaching notification and proof of payment.

Presidential Regulation number 20 of 2018 concerning the Use of Foreign Workers is clearly contradictory to Article 42 to Article 49 of Act Number 13 of 2003 concerning Manpower (Manpower Act). Manpower Act requires the employers of foreign workers to 
have a RPTKA indiscriminately, but in Article 10 paragraph (1) Presidential Regulation of the Use of Foreign Workers stipulates that foreign workers employers are not required to have RPTKA to hire foreign workers which is; Shareholders who are members of the board of directors or members of the board of commissioners to the employers of foreign workers; Diplomatic and consular officials to representatives of foreign countries; Foreign workers on the type of work the government needs.

The State is directly responsible for the fulfillment of state obligations to citizens. If the rights of a citizen are violated by an act against the law committed by the state organs, then the purpose of the process may be the demand for the cancellation of the unlawful act. ${ }^{\left[{ }^{8}\right.} \mathrm{Hans}$ Kelsen through the Stufentheori argues that a legal system is a hierarchy of laws in which a certain legal provision derives from other higher legal provisions. As a higher provision it is Grundnorm or a basic norm that is hypothetical. The lower provisions are more concrete than the higher provisions. ${ }^{[9]}$

One legal norm is always valid, sourced, and based on higher legal norms above it, and higher legal norms also always refer to higher legal norms. And so on to a fundamental norm (Staatsfundamentalnorm) of the Republic of Indonesia, that is Pancasila. Lower regulations should not be contrary to the higher regulation. The system of Indonesian legal norms underlines that Pancasila is the highest legal norm or source of all sources of state law. Levels in Pancasila at the same time occupy the top of the hierarchy of legislation in Indonesia is the 1945 Constitution as the basic rule of the state (Staatsgrundgezetz). ${ }^{[10]}$

Presidential Regulation Number 20 of 2018 concerning the Use of Foreign Workers who are considered contrary to the 1945 Constitution and the Law, and to open wide-ranging entrances to foreign workers, may result in conflict within the country. The conflict occurred because the people, especially the Indonesian workers who felt threatened by the Presidential Regulation and the existence of foreign workers which resulted in the termination of employment and difficulty to get a job.

Conflict as a result of the social mobility phenomena is characterized by a clash between values and interests. Usually the collision will occur because a society there are some who are not ready to accept the changes caused by social mobility. $*$ On the one hand there are individuals or groups actively engaged (directly) in social mobility wanting to renew certain values that are currently in force aimed at legitimizing their positions. ${ }^{\S}$ On the other hand, there are some members of society who still hold the old values and can not simply move on to new values. Thus, these symptoms show the existence of differences in interests between individuals or between groups of citizens and communities. This distinction of interest creates clashes between interest groups in which each party involved in the conflict maintains mutual values and the other seeks to frustrate the interests of others. ${ }^{[11]}$

Conflict is a social phenomena that is present in social life, so that conflict is inherent, meaning conflict will always exist in every space and time, anywhere and anytime. In this view, society is an arena of conflict or an arena of conflict and integration that continues to take place. Conflict and social integration, therefore, is a symptom that always fills every social life. The things that encourage conflict and integration are the similarities and differences of social interests. In every social life there is not a single human having exactly the same, whether of ethnicity, interests, will, purpose, etc. From each conflict there are several that can be resolved, but some can not be resolved resulting in some acts of violence. Violence is a symptom that can not overcome the root of the conflict, causing violence from the smallest model of violence to war.

The nature of one social group overlaps with the nature of other social groups. Thus there is a relationship that affects each other. ${ }^{[12]}$ Social mobility is also the dominance of a social 
group compared to other social groups. This phenomena appears from the demands of new treatment of a social group of rights and obligations, competition between social groups to seize domination and oppression of another group. It should be remembered that social groups are formed by social differentiation in society. This phenomenon leads to a shaky social stability. Conflict between social groups can be: ${ }^{[13]}$

1. The reaction of the oppressed group to the ruler;

2. Violent acts committed by a social group caused by victims of fanaticism; and

3. Protest a social group against the authorities to obtain fair treatment.

Presidential Regulation Number 20 of 2018 gives intimidation to Indonesian workers, Indonesian workers feel the sustainability of their livelihood and their work will be threatened and disturbed by the existence of Presidential Regulation which is facilitate foreign workers to work in Indonesia. The fear may extend to hatred of a certain ethnic group, for example, due to the large number of Chinese foreign workers entering Indonesia, this will create an anti-Chinese sentiment that also affects all Indonesian citizens of Chinese descent. It is still fresh to remember how the 1998 tragedy caused considerable sentiments and damage to Indonesian citizens of Chinese descent. In addition to anti-Chinese sentiments, there will also be public distrust of the government, which will arise public perception that the government is too liberal and pro to foreign. Although Presidential Regulation of the Use of Foreign Worker is assessed to increase investment and economic growth, it must be reconsidered the social impact that will occur in the community, the social impact will trigger a conflict that gives greater damage than the positive impact generated by the Presidential Regulation.

\section{Conclusions}

Based on Popular Sovereignty Theory, Presidential Regulation of the Use of Foreign Workers should pay attention to the Indonesian Workers who interest to get a job, rather than just prioritizing the entry of investment into Indonesia. And based on the Stufentheori Theory if there are lower regulations contrary to higher regulation then the lower regulation can be judicial review to be canceled entirely or partially canceled.

Although Presidential Regulation of the Use of Foreign Workers assessed to increase investment and economic growth, it must be reconsidered the social impact that will occur in the community, the social impact of course will trigger a conflict that could have damaged from the conflict is greater than the possibility of published The Presidential Regulation.

\section{References}

1. Zulkarnaen \& B.A. Saebani, Hukum konstitusi, p. 55-56(Pustaka Setia, Bandung, 2012)

2. Zulkarnaen \& B.A. Saebani, Hukum konstitusi, p. 55-56 (Pustaka Setia,Bandung, 2012)

3. P. L. Berger, Piramida pengorbanan manusia atau jawaban di antara sosialisme dan kapitalisme, p. 17 (Iqra, Bandung, 1983)

4. H. Nawawi, Metode Penelitian Sosial, p. 12 (Laksbang Grafika, Surabaya, 2010)

5. S. Soekanto \& S. Mamudji, Penelitian hukum normatif suatu tinjauan singkat, p. 4 (RajaGrafindo Persada, Jakarta, 2003)

6. Soeroso, Perbandingan hukum perdata, p. 6(Sinar Grafika, Jakarta, 2005)

7. M. Pakpahan, Ilmu negara dan politik, p. 75 (Bumi Intitama Sejahtera, Jakarta Pusat, 2010) 
8. H. Kelsen,Teori umum tentang hukum dan negara, p. 287-288 (Nusa Media, Bandung, 2011)

9. H. Bakir, Kastil teori hukum, p. 110 (PT Indeks Kelompok Gramedia, Jakarta, 2005)

10. A. Syamsuddin, Proses dan teknik penyusunan peraturan perundang-undangan edisi revisi, p. 43 (Anak Negeri Publisindo, Jakarta, 2013)

11.E. M. Setiadi dan U. Kolip, Pengantar sosiologi:pemahaman fakta dan gejala permasalahan sosial: teori, aplikasi, dan pemecahannya, p. 517(Kencana, Jakarta, 2011)

12. C. E. Welch, Political modernization, p. 162 (Wadsworth Publ, Belmont, 1967)

13. E. M. Setiadi dan U. Kolip, Pengantar sosiologi: pemahaman fakta dan gejala permasalahan sosial: teori, aplikasi, dan pemecahannya, p. 517(Kencana, Jakarta, 2011) 